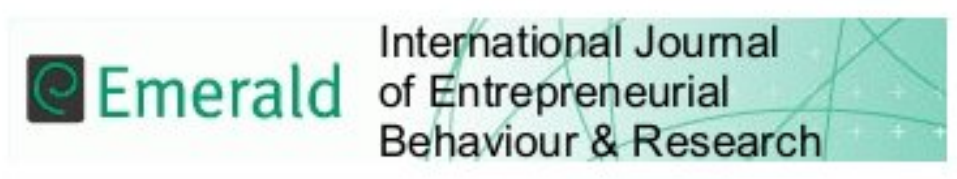

\title{
Entrepreneurial success of cottage-based women entrepreneurs in Oman
}

\begin{tabular}{|r|l|}
\hline Journal: & International Journal of Entrepreneurial Behavior \& Research \\
\hline Manuscript ID & IJEBR-10-2018-0691.R1 \\
\hline Manuscript Type: & Research Paper \\
\hline Keywords: & Gender, Rural \\
\hline \multicolumn{2}{l}{} \\
\hline
\end{tabular}

\section{SCHOLARONE} Manuscripts 


\title{
Entrepreneurial success of cottage-based women entrepreneurs in Oman
}

\begin{abstract}
Purpose: Investigates various problems experienced by cottage based women entrepreneurs to launch and develop their ventures in Oman. The study focuses on women going beyond their traditional family roles for various reasons to establish themselves in Omani society.

Design/Methodology/Approach: A mixed research approach using a quantitative survey of 142 cottage based Omani women entrepreneurs and qualitative face to face interviews with ten women entrepreneurs, presented as six short case studies. The intensity of the business related problems is determined through the exploratory factor analysis (EFA), and Confirmatory Factor Analysis (CFA) is used to confirm the model by determining the goodness of fit between hypothesized model and sample data.
\end{abstract}

Findings: Access to government for current business needs, access to specialized suppliers for staying ahead of the competition and high cost of raw materials were the problems mentioned as being important, while marketing oriented problems were of least concern.

Research Limitations: This study was undertaken in one region of Oman only and thus poses problems when extrapolating the findings to other areas.

Practical implications: Suggests how policymakers can support women entrepreneurs to diversify and start new ventures while simultaneously contributing to the socio-economic development of Oman. s

Originality/value: Research on cottage entrepreneurship in the context of an Arab country is scarce and the study provides an overview of the obstacles and support required for the development of women entrepreneurship in Oman.

Keywords: Women entrepreneurs, cottage entrepreneurship, rural entrepreneurship, Oman

Paper type: Research paper

\section{Introduction}

Ongoing social and political societal changes in developing economies has significantly improved access to higher education, employment, political empowerment and economic independence for women but there are still significant barriers to women (Schindehutte, et al 2003; Ghouse, et al, 2017. Lourenço, et al 2014). Although gender equality in the areas of education and workplace, continues to improve and nuanced understanding of how gender influences entrepreneurial action 
also expands, (Smith, 2014) their traditional roles remains relatively unchanged (Winn, 2004). Many women prefer to establish their own business after child birth instead of returning to paid employment, believing that self-employment will provide a better balance between work and family. Thus, women choose entrepreneurial platforms with varying bundles of expectations despite their prior limited entrepreneurial or intrapreneurial exposure. This is particularly true in developing economies, such as Oman where traditional gender divisions of labour are still strong. Winn $(2004,151)$ considers many of these women's expectations unrealistic. Clearly, women entrepreneurs play an important role in the development of small business enterprises in so called transition economies (Lerner et al., 1997). Several studies, in both developing countries like Oman, (Ghouse et al., 2018), Iran, (Hosseini and McElwee, 2011), Uganda, (Lourenço et al., 2014), India, (Kumbhar, 2013) Pakistan, (Muhammed et al, 2017) the Middle East (Mathew, 2010) and in developed economies, (De Rosa and McElwee, 2015, 2019) show that women's entrepreneurship can become an essential driver of economic growth. Fergany (2003) suggests that private sector growth, particularly in the small business sector, where women contribute to growth substantially, could benefit social and economic problems in Arab countries. Influenced by growing trends, the number of Arab women entrepreneurs is growing providing increasing career prospects for women to initiate, shape and manage their own businesses (Tlaiss, 2015; Dechant and Lamky, 2005). There has been little research on the problems experienced by Arab women entrepreneurs as most research on women entrepreneurship is in western or developed economy contexts (Al-Dajanim and Marlow, 2013; Marlow and McAdam, 2015). This gap in the literature and extant research is then the research problematic.

In many least developed Arab countries, where gender divisions are strongest, women entrepreneurs tend to choose to establish their initial businesses in the informal micro sector 
focusing on traditional non-technical goods and services. These small sized enterprises produce simple cottage-based items, mainly for localised markets. Wider market access poses a challenge due to socio-cultural factors and geographical remoteness. In the main, women owned enterprises are smaller and less profitable compared to men owned enterprises. However, women entrepreneurs tend to employ female workers, hence contributing to economic growth as well as addressing issues of the women empowerment and economic engagement.

The aim of the paper is to present an exploration of the problems experienced by cottage based Omani Arab women entrepreneurs on the success of their business enterprises. The research question is simple - what are the specific issues which Arab Omani women face in setting up and running their cottage-based enterprises.

The paper is structured as follows.

A context to Oman is presented. We then discuss the nature of women entrepreneurs in Oman highlighting the key issues in the literature before outlining the research methodology and findings. Based on a mixed research approach, the research provides insights of the types of problems experienced by women entrepreneurs through the results of a survey of 142 respondents as well as qualitative short case studies on 5 women entrepreneurs. Valuable insights are provided based on the problems experienced and the expectations of the women entrepreneurs. The findings of this research, in this relatively unexplored field, have implications for Arab female entrepreneurs seeking to establish and grow their business ventures, for educators/trainers seeking to help women develop competencies and for those in agencies working to support more women to view venturing as a viable/desirable career. 
The Omani context: Though Oman is comparatively less rich as compared to its oil rich gulf neighbours, the gulf nation has focused on economic diversification rather than depending upon hydrocarbons (https://bit.ly/2CDQSOj). Oman has focused on developing its key infrastructure: seaports, railways and the airports through its eighth five year plan (2011-2015) in order to be a major logistics hub (Oxford Business Group, 2016). The ninth five year plan (2015-2020) has identified three key strategic sectors logistics, manufacturing and tourism regarded crucial in the development of Oman's economy (www.scp.gov.om). A World Bank publication "Oman Economic Outlook" suggests Oman's economic growth to recover modestly with a $2.3 \%$ increase in 2018 and 2.5\% in 2019 in Gross Domestic Product (GDP). Oman has a young population, with $40 \%$ under twenty-five years and requires stringent economic reforms to create sustainable employment (https://bit.ly/2x0t29Z).

The decline in oil prices led the government to accelerate economic diversification and to increase the role of the private sector. The Omani Vision 2020 is based on four pillars: Economic Balance and Sustainability; Human Resource Development; Economic Diversification and Private Sector Development (www.scp.gov.om). Economic diversification is encouraged through promoting foreign investment, executing a robust strategy for the SMEs, boosting industrialization, developing modern infrastructure, and expanding the private sector involvement (https://bit.ly/2CCzxVT). The government seeks to achieve this goal by promoting a culture of entrepreneurship in the Sultanate. Nearly half of the population live in the Muscat area and the AlBatinah region in northern Oman. The southern region of Dhofar is dominated by 200,000 people while 30,000 people inhabit the Musandam peninsula on the strategic Strait of Hormuz. In Oman, $78 \%$ of the population is urbanized. Females constitute approximately $33 \%$ of the total population (World Population Review, 2016) and their representation in the higher education is around 5\%. 
The number of Omani females working in public offices, boards and specialized centers (health, community, social, etc.) is $41.5 \%, 24 \%$ working in private sector while the share in civil services is $47 \%$ in 2016 (Times of Oman, 136123). Though female engagement in governance and industry is growing, there is little empirical evidence of the various problems women undergo in order to participate and be successful in these areas. Women entrepreneurs epitomize a significant untapped human resource, an omission that deserves consideration.

\section{Female entrepreneurship: Engagement, Motivations and expectations}

2.1. Entrepreneurial engagement: Reynolds suggests that men are more likely to initiate and run entrepreneurial ventures and consequently, government agencies in many countries are promoting policies aimed towards women to support entrepreneurship and business startup (Reynolds et al. 2004). In developed economies women are increasingly establishing their own ventures. In the USA for example the number of women owned firms are increasing (Wilson, et al, 2004). Figures, for developing economies are much more difficult to obtain as many women entrepreneurs tend to set up informal enterprises. What appears to hold true however is that that women tend to establish ventures in traditionally female dominated areas; retail, handicrafts, aromatic production, etc. but not in traditionally male dominated areas, such as science, engineering, technology, etc. (Al-Sadi, 2011; Allen et al. 2008; Anna et al. 2000). Women work in micro-level entrepreneurial businesses leading to stability rather than growth and usually have less access to external funding than men (Boden and Nucci, 2000). Consequently, their businesses tend to be concentrated in the service sectors that require low initial investment and technical knowledge.

2.2 Entrepreneurial Motivations: To start an entrepreneurial venture, men and women are considered to have similar entrepreneurial skills and qualities and equally likely to be innovative 
(Davis and Long, 1999). Though some motivations of men and women entrepreneurs tend to be similar, such as a desire for independence and financial gain, in research undertaken by Mattis, women respondents cite their flexibility and childcare obligations as a strong motivation for taking the steps to establish and build a business (Mattis 2004). A woman's decision to establish her own business venture is subject to a combination of push and pull factors, not shared by men. Some suggest push factors are more predominant (Carter and Shaw, 2006; Walker and Webster, 2007). Limited research has explored the expectations which female entrepreneurs have for an improved work-family balance and reflected on their actual experiences (Carter and Shaw, 2006; Lewis 2006; Rouse and Kitching, 2006; Williams, 2004), while some engage in entrepreneurship to balance work-life responsibilities (Marlow and Strange, 1994). Lassale and McElwee (2016) suggest that women in developing countries are particularly dependent on available opportunity structures. These can be available at both a national level, covering institutions, laws, rules and regulations and culture (Kloosterman and Rath, 2001) and at a personal level, i.e. the personal characteristics of the woman entrepreneur, and family or peer support (Somerville and McElwee, 2011). Family support and self-inspiration are often crucial for motivation of a woman entrepreneur, sometimes an inclusion of the role models and mentors is found to be influential (Brynin and Schupp, 2000). Not surprisingly, Sidhu and Kaur (2006) suggest that sound technical knowledge, business skills, innovative ideas and previous exposure and an extensive availability of these factors within a society enhance the growth of women entrepreneurship.

2.3 Entrepreneurial expectations and outcomes: Entrepreneurs have certain expectations related to their venture to be successful (Gatewood et al. 2002). Entrepreneurs often start business ventures with idealistic expectations with a lack of proper understanding of the risks involved 
(Cromie, 1987). Developing and maintaining an entrepreneurial venture which is small and stable, and accommodates family, social and personal life aspects can be regarded as a measure of success for woman entrepreneurs rather than going for growing big business ventures argue Lee-Gosselin and Grise (1990). Women entrepreneurs can choose the best option that suits their personal priorities, be they home-centred, work-centred, or a balance of the two lifestyle preferences (Hakim, 2003). Work and family are interdependent but not different spheres with domestic boundaries, and the roles can merge and clash (Desrochers and Sargent, 2004). The motivation to start a new entrepreneurial venture is prompted by the expectations driven by previous exposure to entrepreneurial success (Robertson et al. 2003).

Although the number of formally registered small and medium enterprises (SMEs) in Oman is small, the government in close coordination with the Central bank of Oman are providing infrastructure and training to promote a culture of enterprise (Al Barwani et al., 2014). It is not clear yet, how successful this initiative is. SMEs in Oman are considered vital in order to increase economic diversification, creating employment opportunities, achieving equal distribution of the resources, and finally to engage women in enterprise (Varghese, 2011, Bilal et al., 2015). Such developments leading to women empowerment can lead to multiple societal benefits and economic growth (Singh and Belwal, 2008). Women entrepreneurs should be more independent of their male partners as well as other relatives, which would ultimately lead more engagement in wider society by women (United Nations, 2007). This view is supported by evidence which suggests the development of female entrepreneurship leads to the progress of women in developing economies (Galloway et al., 2002). Of course progress is a relative concept.

2.4 Research Methodology: The unit of analysis for this study is cottage based Omani women entrepreneurs in the Dhofar region. Dhofar is located in the southern part of Sultanate of Oman, 
traditionally termed as the "Land of Frankincense", dominated by a tribal ethnic population. Female business owners, working from their homes in the Dhofar region were targeted for the research survey. Many enterprises are established in the informal economy and in particular, those which operate in rural areas.

Business support managers from regional chambers of commerce helped identify prominent cottage-based women entrepreneurs operating in the Dhofar region, and subsequently from referrals made by the women entrepreneurs themselves (snowball sampling). The study was conducted in the time period February-May 2018 and was organized in three different stages. Stage one involved a pilot study of ten women entrepreneurs. This stage helped to check the reliability and the content of the questionnaire. Stage two involved the main survey using an indepth bilingual questionnaire in English and local Arabic languages. Structured as well as unstructured type questions both were included in the instrument. The quantitative measures were made on a five-point Likert scale ranging from 1 (strongly disagree) to 5 (strongly agree). The female respondents were contacted through the telephone requesting their participation in the survey. A guarantee of anonymity was made to the respondents. An initial contact with 64 cottagebased women entrepreneurs was made out of which six declined to participate, four were unavailable and in two cases, a meeting was cancelled. The initial participants in the study provided names of several other women entrepreneurs working from home, and a data of 142 women entrepreneurs was collected through the second stage survey. Data analysis was made by grouping the problems to success in a model under four problem categories through the Exploratory Factor Analysis (EFA). Confirmatory Factor Analysis (CFA) was employed to confirm the exploratory factor model by determining the goodness of fit between hypothesized model and sample data. The subjects of prime importance and the relevant issues, were collected 
and recorded. The third stage of the research investigation involved face to face interviews with five women entrepreneurs from the Dhofar region, who had earlier participated in the survey. The interviews were framed on the basis of the information collected through the questionnaire, which ultimately went on to inform the case studies. A descriptive multiple case study approach was aimed (Yin, 2004), the evidence-based practice approach (Given, 2006) resulted in more textured information related to the problems and the prospects in the cottage-based women entrepreneurship.

\section{Findings:}

The results of the quantitative survey are tabulated and discussed as below. INSERT TABLE 1 ABOUT HERE

Table 1 shows that most of the respondents were the sole proprietor of their enterprise. The majority $(56.3 \%)$ of the companies had been established before two years. The women entrepreneurs represented a range of age groups, but only $(15.5 \%)$ were younger than 25 . And $33.8 \%$ of respondents were between $25-34$ years old. Table 1 also shows that more than $73 \%$ of women entrepreneurs were educated to a basic level, but only $23.9 \%$ of the respondents had a university degree, and $2.8 \%$ of the respondents had a Masters/Ph.D.

INSERT TABLE 2 ABOUT HERE 
The respondents' were working in largely Frankincense/ Perfumes/ Aromas sectors, followed by apparel/clothing, then accommodation and catering, whilst unsurprisingly the Construction sector has little representation.

\section{INSERT TABLE 3 ABOUT HERE}

$36.6 \%$ of respondents deal with two types of international trade (Export \& Import).The table reveals that $60.6 \%$ of respondent's revenue had increased, and $29.5 \%$ of respondents' revenue had kept on same of the revenue, while $9.9 \%$ of respondents' revenue had decreased.

\section{INSERT TABLE 4 ABOUT HERE}

Table 4 shows that more than half the respondents start their businesses to make more money or supplement the family income. Respondents were asked to select the most significant obstacles they faced during the creation of their venture. Table 4 illustrates that this was lack of selfconfidence followed by balancing the time demands of work and family. In all, $22.5 \%$ of respondents felt that their lack of financial resources was an issue. 7.\% mentioned the lack of social networks as a challenge. 4.\% said that lack of support of the family was a problem. Lack of acquiring credibility and trust from others, and lack of information about the sector were mentioned by $3.5 \%$ and $2 \%$, respectively. Social networking is a key entrepreneurial skill and is hindered by geographical isolation. 


\title{
INSERT TABLE 5 ABOUT HERE
}

Table 5 displays behaviours of women entrepreneurs.

\section{INSERT TABLE 6 ABOUT HERE}

\begin{abstract}
Table 6 shows that the most important ways that government could improve support for small businesses in Oman is set up special loan or investment funds to spur innovation, followed by provide targeted business skills training for growth-oriented or innovative businesses, then reduce the formalities and time to register and start a new business. While the less important way to support ventures of women entrepreneurs was to align tax policies with the encouragement of new business formation and innovative activities. This is particularly important.
\end{abstract}

\section{EFA \& CFA:}

The findings of the current study are depicted in table 7 below:

\section{INSERT TABLE 7 ABOUT HERE}

\author{
To determine the dimensions of business problems for women entrepreneurs in Oman EFA was \\ used through the principal components by the Varimax method. EFA revealed the existence of \\ four variables through the entered items as shown in Table 1 (i.e. Governmental Problems, Capital \\ Problems, Marketing Problems, and Social Problems). In view of Table 1, it is noted that all


conditions of $(\mathrm{EFA})$ have been achieved. $(\mathrm{KMO}=0.629>0.60$, Bartlett's Test $=601.655$, Sig. $=$ $0.000<0.05$, Cumulative Variance $=62.99>60$ ). Also, Table 1 revealed the values of Cronbach's Alpha for all the variables were within the acceptable range $(>0.60)$.

\section{INSERT FIG 1 ABOUT HERE}

EFA revealed four factors, subsequently CFA was conducted using AMOS 25. CFA was used to confirm the exploratory factor model by determining the goodness of fit between hypothesized model and sample data as shown in figure 1.

\section{INSERT TABLE 8 ABOUT HERE}

The results mentioned in Table 8 indicate a good fit of the model that was tested according to Kline (1998). Thus, the results of confirmatory factor analysis were positive.

INSERT TABLE 9 ABOUT HERE

According to EF) as shown in Table 8 there are four types of problems: (Governmental Problems, Capital Problems, Marketing Problems, and Social Problems). The same table shows that the most important problems in business for women entrepreneurs in Oman concerned keeping up with the latest technology, followed by access to funds for longer-term growth. Access to Government support for current business needs, access to specialized suppliers for staying ahead of the competition and reforming laws and regulations that hamper business growth were also mentioned as being important. Interestingly the lowest scoring issue was Availability/sustainability of the local trained labour. So labour shortages does not appear to be an issue in rural Oman, unlike in developed economies. 


\title{
INSERT TABLE 10 ABOUT HERE
}

\begin{abstract}
Table 10 shows that capital problems is the highest mean (3.580), followed by governmental problems (3.330), then marketing problems (3.270), and the lowest mean is social problems (3.138). All values of standard deviations were low; this means that there is no dispersion in respondents' answers. The relationships between all the study variables were significantly and positively correlated at level 0.01 , and correlation coefficients between all the variables were less than 0.80 .
\end{abstract}

\section{Hypotheses:}

1. There are no significant differences between company types for women entrepreneurs in term of recognition of business problems dimensions. Rejected

2. There are no significant differences between married and unmarried women entrepreneurs in term of recognition of business problems dimensions. Accepted

3. There are no significant differences between the age groups of women entrepreneurs in term of recognition of business problems dimensions. Rejected

4. There are no significant differences between education levels in term of recognition of business problems dimensions. Accepted

5. There are no significant differences between industry categories for women entrepreneurs in term of recognition of business problems dimensions. Rejected

\section{Test of Hypothesis:}


To test the hypotheses we used independent samples T-Test in case the demographic variable consists of two categories (Gender \& Qualification), and One Way ANOVA in case the demographic variable consists of more than two categories (Universities \& Age).

INSERT TABLE 11 ABOUT HERE

Table 11 shows the results of independent samples T-Test of business problems, company type and marital status. The results indicate the existence of significant differences between sole proprietorship and partnership with regard to all dimensions of business problems except social problems. Table 4 points out no differences between married and unmarried of women entrepreneurs.

\section{INSERT TABLE 12 ABOUT HERE}

Table 12 shows the results of One Way ANOVA of business problems, according age, education, and industry. The results indicate to existence significant differences between age groups regarding all dimensions of business problems except social problems. Table 12 indicates the significant differences between the education levels regarding only one dimension of business problems, namely capital problems Also, Table 12 indicates to existence significant differences between industry categories with regard to all dimensions of business problems, namely (governmental problems, capital problems, marketing problems, and social problems).

The next section complements the quantitative data with some rich case studies. 
Qualitative Case Studies ${ }^{1}$

\section{Category: Leather Handicrafts (1)}

\section{Workplace: Home}

This case study entails the entrepreneurial journey of two sisters (Maryam and Kali) based in Thumrait, Dhofar who are successfully running a leather handicrafts business. The two sisters started the business in 2014 after going through an intensive five years vocational training provided by the government leather training centre in Thumrait. They were well supported by their brother in their entrepreneurial venture who is an employee in one of the public offices in Oman. Being aware of the requirements of training, a capital amount of OMR 20,000.00 was initially raised, $75 \%$ through a bank loan while the remaining $25 \%$ through personal finances and invested in arranging the necessary infrastructure to start the business at the home. They manufacture a variety of leather based handicraft items: gift boxes, khanjer belts (traditional Omani belts), picture frames, file covers, bags, etc. in leather which they usually buy from a known supplier in Egypt. The annual turnover is over OMR 10,000.00. The main objective for the sisters to start the

${ }^{1}$ All names are pseudonyms 
business venture was to capitalize on their intensive training and to provide an inspiration to the traditional desert women through their success story. They normally acquire business contacts through social contacts, and by participating in exhibitions organized by the government. They are looking to expand the business and aim to develop outlets for greater sales in government offices and educational institutions in the Dhofar region as well as Muscat area. They note several marketing oriented problems in their business, the cost of sourcing the raw material from Egypt, local competition from the similar non-leather products as well as the market being saturated with low priced Chinese products.

"Business demands persistence, commitment and an ability to bear the pain through the entrepreneurial journey to get established in the market".

They also suggested that backward integration and expansion into the local processing of the raw material in Oman rather than importing from other countries, which can help establishment of several business enterprises and generate employment in Oman and reduce costs. Local processing could also help in the adjustment of the handicraft prices which could attract the price conscious customers.

Key themes

Networking critical for business success

Expansion desirable but competition is keen

Growth is only possible through exploiting the value chain

\section{Category: Sewing and Traditional Aromas (2)}




\section{Workplace: Home}

Low family income pushed Umm Said to start a home based business based on her skills of sewing and knowledge about scent to make locally preferred traditional perfumes, commonly known as bakhoor. Her husband is a taxi driver and his income is not enough to support the family, hence Umm Said decided to find an alternative source of income to support the family. Deterred by the non-availability of the capital, she utilized her savings to commence her cottage based entrepreneurship by purchasing a sewing machine with which she started to sew clothes for the women in her neighbourhood for a small amount of money. She continued to work as a dressmaker for years which made her very respectable in her community. Her success in the sewing business led her to divest into the business of incense perfumes known as bakhoor widely uses in every Arab household. Though bakhoor is made by most of Omani women, the key skill is in mixing the raw perfumes with the base. Her acquaintance with the perfumes and the aromatic oils made her to develop the bakhoor which got a warm response from the industry. In a short time, the name Umm Said become well known in the industry for the quality, distinctive products and the credibility of the business. Understanding market segmentation, meant that Umm Said is able to sell different versions of bakhoor. Being a mother of young children, a housewife and an entrepreneur was really a difficult task for Umm Said but she didn't give up the task as family development was her first priority. Um Said overcame all obstacles and succeeded as a cottage entrepreneur.

Key themes

Lack of access to capital

Push factors

Technical skills

Category: Printing \& Designing (3) 


\section{Workplace: Home and Factory}

Fatima is based in Mirbat in the Dhofar region dealing in designing and printing cards and logos from her home. She is creative and ambitious and started thinking about setting up her own business when she was in high school. She enrolled at the university but was not able to complete her degree due to some personal reasons. After her marriage, she decided to realize her vision of owning a business enterprise. She successfully introduced the idea of designing and printing cards for different occasions to her family seeking their financial and social support in order to start a small business from her home. She started the business in 2015 after purchasing the printers and a new computer from her savings. Fatima started designing cards and stickers for family and social gatherings. She experienced problems at the conception of the business in the form of finance, finding the designing \& printing software and in learning to use the new advanced printers. Fatima got a good response and became well-known for printing and designing. She started promoting her work through the social media and got even better response. The demand for her designing skills grew larger, she had even designed logos for other designers and enterprise owners in Mirbat and surrounding towns. Just to enhance and further develop her designing skills, she attended and enrolled herself in several related technical sessions in Muscat and Dubai. Though she experienced many problems in her successful entrepreneurial journey, her determination and family support provided herwith the confidence to develop the business.

Key themes

Self-efficacy

Vision

Strategic thinking capability

Technical skill 
Marketing through social media

\section{Category: Abaya designing (4)}

\section{Workplace: Home \& Shop}

Malak is a cottage entrepreneur who owns a traditional Omani apparel business in the small town of Taqah. She designs, manufactures and sells traditional Abaya (veil) from her home, under the brand name AKZ ABAYA. Capitalizing on her sewing and embroidery skills seeking the possibilities for an additional income to manage a big family, Malak started the unregistered venture in 2009 as a sole owner/employee after getting a supportive fund of RO500 from the government. Malak initially experienced the problems in the promotion of her goods and finding customers. In 2012 Malak started to use the social media tools like Instagram, WhatsApp, Facebook, etc. to promote her business and target new customers. This resulted mainly in a substantial growth in the number of young customers and led to her participating in exhibitions and traditional crafts fairs in Oman. According to Malak, many married Omani women perceive doing business a difficult task due to social obligations. However, it was Malak's family which supported and motivated her to succeed in her entrepreneurial journey. Malak added though the cultural norms for women entrepreneurs in Oman are tough, they could be managed by careful planning. She stressed that product innovation was a significant barrier as the consumers' tastes are shifting from traditional dresses to a more western style or a mix of the two, mainly due to social media usage. Since she lacks a professional fashion designing education, she often finds it difficult to create new designs and incorporate contemporary fashion in Abaya. She thinks recent technological innovations provide many opportunities for women entrepreneurs as they facilitate cottage based small-scale businesses. She believes that such opportunities will generate additional family income leading to better lifestyle in Oman. 
Key themes

Informality at first

Social media

Family support

\section{Category: Bakhoor Trade (5)}

\section{Workplace: Home}

Muna is a middle aged cottage based woman entrepreneur Muna who has run a highly profitable unbranded business of traditional incense Bakhoor for more than three decades. The product also reflects the national heritage of Oman. The bakhoor business is a simple trade with a high profit margins. Muna fully operates and sells the Bakhoor from her home which saves a lot of expenses including rental, promotional, legal, labor, etc. instead of operating directly into the market. She has a specialty and is highly skilled in blending the perfumes used in making bakhoor due to which she has elite loyal customers all over Oman as well as other GCC countries. She is widely known among Arabs for her high quality bakhoor which is purchased for marriages parties as well as for special occasions. She regularly participates in the local exhibitions supervised by the Ministry of commerce and industry which help her in promoting her bakhoor to the local customers as well as Khareef* tourists. Muna refrains from opening her own shop due to several reasons: societal obligations as well as to avoid the overhead costs involved. In addition to that, home-trade is not time-bound, and there is no harm if a time comes where you are forced to stop. Another problem which refrains her from open trading Bakhoor in the market is her family's situation and the social environment which doesn't allow her to operate directly in the market.

"To be successful in a competitive market, you have to develop a specialty and competence!" 
*The monsoon season from July to August. In Arabic, خريف, it is a colloquial Arabic term used in the Dhofar region of Oman

Key themes

Cottage based industries low overheads

Technical skills

Lifestyle business

\section{Category: Food Business (6)}

\section{Workplace: Home}

Noor had a keen interest in cooking since her childhood which she developed into a talent with her growth. She used to accompany and support her mother while cooking the food. Her interest in cooking led her to learn different cuisines through her mother, family friends as well as internet based YouTube videos. After finishing her studies and getting married in a moderate Omani family, she planned to utilize her cooking skills. She spent her free time watching cooking shows and learning food recipes. Her cooking brought recognition to her within and outside the family which motivated her to start an entrepreneurial venture which could support her growing family expenses in 2007. From the inception, the biggest obstacle Noor faced was the access to capital for her establishment as well as practice because of the unavailability of the personal capital. She experienced problems in the raw materials and the ingredients required for the varieties of the dishes. Her stubborn nature led her to face the obstacles experienced during her journey of cottage entrepreneurship. She borrowed money from her family friends to take care of her business whenever needed and continued to work until she became experienced in organizing her time and taking orders. Within a few months, she became one of the most famous female (home-based) cooks in Salalah. She sought the help of social media through Instagram so she could get in touch with the community and post pictures of the dishes she made. She had also started making customized 
dishes depending on the customers' wants. This cottage based enterprise provided her and her family a new source of income.

Key themes

Access to capital

Technical skills

Conclusion

This research is to explore the experiences of the entrepreneurial journey of Omani women who have set up their own home based business ventures, consider their needs when engaged with the process, reflecting their entrepreneurial motivations, and the outcomes through entrepreneurship on the basis of their experiences. The limited literature on Omani women entrepreneurs reflected has not examined the particular issues facing, in particular rural women entrepreneurs.

This is the first example of an attempt to look at the issues facing these women.

The emergent themes from the case six case studies, show that a developed technical skill, a willingness to use social media and appreciation and understanding of markets is critical for success. These entrepreneurial skills, coupled with an ability to challenge social mores which tend to traditionally restrict the opportunities for women appear to be significant ingredients for entrepreneurial success. An earlier study in Omani context advocates the role of policy makers to support the women entrepreneurs in their income diversification by starting new business ventures (Ghouse et al, 2017). However, although there appears to be a significant change in the policy direction to encourage support for new venture creation, the women in this study have engaged in 
a willingness to launch their own ventures, despite the lack of either government support or the limitations of obtaining financial support outside of the traditional networks of family and friends.

The mixed research approach taken in the paper has allowed a rich set of narratives to unfold in the cases supporting and enhancing the results of the quantitative element.

The research provides thorough insights about the cottage women entrepreneurs about starting a business enterprise managing their ventures despite the variety of problems related to them. The research supports the work of Mattis (2004) which proposes balancing familial responsibilities as the key drive in the women to engage themselves into entrepreneurship along with a desire to be their own boss, and women entrepreneurs need to be flexible in order to realize their ambitions. The research also supported the findings of Walker and Webster (2007) indicating the desire for personal independence as the motivating factor to get engaged into entrepreneurship. So there appears to be a clear link in our findings to the earlier literature issues raised in section 2.2.

In the Omani context it appears that women entrepreneurs tend to employ female workers, thus contributing to both economic growth as well as addressing issues of women empowerment and economic engagement. These factors in themselves suggest that even greater participation in the labour market and increased venture creation could be possibly achieved if policymakers, financial institutions, leading social elements and the media identified the methods to enable, support and promote start up opportunities for Arab women business. Simple measures in rural areas in terms of training, seed corn funding, enterprise support for young people, could help in the Omani 2020 vision. The results of the empirical quantitative stage in particular highlights the importance of 
government support. In earlier work, Smith and McElwee, (2013), show how policy support: tax breaks for small business start-up, reduced business rates, entrepreneurial training and so forth, can help to reduce the number of businesses that remain in the informal economy

Our results then suggests that Omani policymakers should consider how women entrepreneurs can be better supported so that they can diversify their household incomes by starting new ventures while simultaneously contributing to the socio-economic development of the region. A number of suggestions on how this can be achieved have been presented.

Research on rural women entrepreneurship in the context of an Arab country is scarce and the study can provide an overview of the obstacles and the support required for the development of the rural women entrepreneurship in this region.

This paper suggests that the informal activities of Arab women entrepreneurs and the ways in which they overcome socio-cultural barriers to make successes of their ventures is an area of interest which is particularly under researched posing particular challenges, particularly for government agencies tasked with increasing the participation of women in the workforce. 


\section{References}

Al-Dajani, H., Marlow, S. (2013) "Empowerment and entrepreneurship: a theoretical framework", International Journal of Entrepreneurial Behaviour \& Research, Vol. 19 Issue: 5, pp.503-524

Al Barwani, K.M., Al Jahwari, M.R., Al Said, A.S. and Al Mahrouqi, F.S. (2014), "Towards a Growing Competitive and Dynamic Small and Medium-Sized Enterprises Sector in Oman: Strategy and Policies", Central Bank of Oman, London.

Al'Omairi, T. and Amzat, I.H. (2012), "Women in Omani society: education and participation", OIDA International Journal of Sustainable Development, Vol. 3 No. 5, pp. 63-80.

Al-Sadi, R., Belwal, R. and Al-Bad, R. (2011), "Women entrepreneurship in the Al-Batinah Region of Oman: an identification of the barriers", Journal of International Womens Studies, Vol. 12 No. 3, pp. 58-75.

Allen, I.E., A. Elam, N. Langowitz, and M. Dean. (2008). Global entrepreneurship monitor: 2007 report on women and entrepreneurship. Wellesley, MA: Babson College.

Anna, A.L., G.N. Chandler, E. Jansen, and N.P. Mero. (2000). Women business owners in Traditional and non-traditional industries. Journal of Business Venturing 15, no. 5 pp279303.

Bennett, R., and S. Dann. (2000). The changing experience of Australian female entrepreneurs. Gender, Work and Organization 7, no. 2: 75-83.

Buttner, E.H., and D.P. Moore. (1997). Women's organizational exodus to entrepreneurship: Self-reported motivations and correlates with success. Journal of Small Business Management 35, no. 1: 34-46.

Carter, S., and E. Shaw. (2006). Woman's business ownership: Recent research and policy developments. Report to the small business service,

Cromie, S. 1987. Similarities and differences between women and men who choose business proprietorship. International Small Business Journal 5, no. 3: 43-60.

Davis, S.E.M., and D.D. Long. 1999. Women entrepreneurs: What do they need? Business and Economic Review 45, no. 4: 25-6.

Dechant, K. and Lamky, A.A. (2005), "Towards an understanding of Arab women entrepreneurs in Bahrain and Oman", Journal of Developmental Entrepreneurship, Vol. 10 No. 2, pp. 123-140.

Desrochers, S., and L.D. Sargent. 2004. Boundary/border theory and work-family integration. Organisation Management Journal 1, no. 1: 40-8.

DeRosa, M., \& McElwee. G. (2015) 'An empirical investigation of the role of rural development policies in stimulating rural entrepreneurship in the Lazio Region of Italy' Society and Business Review 10(2) 4-22

DeRosa, M., McElwee, G., and Smith, R. (2019) ,Farm diversification strategies in response to rural policy: A case from rural Italy'Land Use Policy 81 219-301

Easterby-Smith, M., R. Thorpe, and R. Lowe. 1991. Management research: An introduction. London: Sage.

Galloway, L., Brown, W. and Arenius, P. (2002), "Gender based differences in entrepreneurial behaviour", International Journal of Entrepreneurship and Innovation, Vol. 3 No. 2, pp. 109-119. 
Gatewood, E.J., K.G. Shaver, J.B. Powers, and W.B. Gartner. 2002. Entrepreneurial expectancy, task effort, and performance. Entrepreneurship Theory and Practice 27, no. 2: 187-206.

Ghouse, S., McElwee, G., Meaton, J. \& Durrah, O. (2017) "Barriers to rural women entrepreneurs in Oman", International Journal of Entrepreneurial Behavior \& Research, Vol. 23 Issue: 6, pp. 998-1016.

Hakim, C. 2003. A new approach to explaining fertility patterns: Preference theory. Population and Development Review 29, no. 3: 349-74.

Lassale, P. \& McElwee, G. (2016) 'Polish Entrepreneurs in Glasgow and Entrepreneurial Opportunity Structure' International Journal of Entrepreneurial Behaviour \& Research 22(2) 260-281

Lee-Gosselin, H., and J. Grise. 1990. Are women owner-managers challenging our definitions of entrepreneurship? An in-depth study. Journal of Business Ethics 9, nos. 4-5: 423-33.

Lewis, P. 2006. The quest for invisibility: Female entrepreneurs and the masculine norm of entrepreneurship. Gender, Work and Organization 13, no. 5: 453-69.

Lourenço, F., Sappleton, N., \& McElwee, G. (2014) 'Experience of entrepreneurial training for female farmers to stimulate entrepreneurship in Uganda' Gender in Management: An international journal 29(7), 382-401

Marlow, S. 1997. Self-employed women: New opportunities, old challenges. Entrepreneurship \& Regional Development 9, no. 3: 199-210.

Marlow, S., and S. Carter. 2004. Accounting for change: Professional status, gender disadvantage and self-employment. Women in Management Review 19, no. 1: 5-17.

Marlow, S., and A. Strange. 1994. Female entrepreneurs - success by whose standards? In Women in management: A developing presence, ed. M. Tanton, 172-84. London: Routledge.

Mathew, V. (2010), "Women entrepreneurship in Middle East: understanding barriers and use of ICT for entrepreneurship development", International Entrepreneurship Management Journal, Vol. 6 No. 163, pp. 163-181.

Mattis, M.C. 2004. Women entrepreneurs: Out from under the glass ceiling. Women in Management Review 19, no. 3: 154-63.

McElwee, G. (2003), "Women entrepreneurs in Oman: some barriers to success", Career Development International, Vol. 8 No. 6, pp. 339-346.

Muhammed, N., McElwee, G \& Dana, L.D (2017) 'Barriers to the Development and Progress of Entrepreneurship in Rural Pakistan' International Journal of Entrepreneurial Behaviour \& Research 23(2) 279-295

Naser, K., Mohammed, W.R \& Nuseibeh, R. (2009),"Factors that affect women entrepreneurs: evidence from an emerging economy", International Journal of Organizational Analysis, Vol. 17 No. 3 pp. 225 - 247

Oman Times (2016), "More female students enrolling in Oman HE", available at: http://timesofoman.com/ article/91820/Oman/Education/More-female-students-in-Omanenrol-in-higher-educationinstitutes-in-the-new-academic-year (accessed 25 April 2017).

Oxford Business Group (2016), "The Report: Oman 2016", available at: www.oxfordbusinessgroup.com/ oman-2016 (accessed 25 April 2017).

Reynolds, P.D., W. Bygrave, E. Autio, L.W. Cox, and M. Hay. 2004. Global entrepreneurship monitor 2003: Executive report. Babson College/Ewing Marion Kauffman Foundation: London Business School. 
Robertson, M., Collins, A. Medira, N. and Slater. J. 2003. Barriers to start-up and their effect on aspirant entrepreneurs. Education + Training 45, no. 6: 308-16.

Rouse, J., and J. Kitching. 2006. Do enterprise support programmes leave women holding the baby? Environment and Planning C 24: 5-19.

Schindehutte, M., M. Morris, and C. Brennan. 2003. Entrepreneurs and motherhood: Impacts on their children in South Africa and the United States. Journal of Small Business Management 41, no. 1: 94-107.

Smith, R (2014) Assessing the contribution of the 'theory of matriarchy 'to the entrepreneurship and family business literatures International Journal of Gender and Entrepreneurship Vol 6 issue 3 pp. $255-275$

Smith, R., \& McElwee, G (2013) 'Confronting Social Constructions of Rural Criminality: A Case Story on 'Illegal Pluriactivity' in the Farming Community' Sociologia Ruralis 53(1) $112-134$

Tails, H.A. (2015), "How Islamic business ethics impact women entrepreneurs: insights from four Arab middle-eastern countries", Journal of Business Ethics, Vol. 129 No. 4, pp. 859877.

United Nations (2007), Developing Women's Entrepreneurship and E-Business in Green Cooperatives in the Asian and Pacific Region, New York, NY.

Varghese, T. (2011), "Women empowerment in Oman: a study based on women empowerment index", Far East Journal of Psychology and Business, Vol. 2 No. 2, pp. 37-53.

Walker, E.A., and B.J. Webster. 2007. Gender, age and self-employment: Some things change, some stay the same. Women in Management Review 22, no. 2: 122-35.

Williams, D.S. 2004. Effects of childcare activities on the duration of self-employment in Europe. Entrepreneurship Theory and Practice 28, no. 5: 467-85.

Wilson, F., D. Marlino, and J. Kickul. 2004. Our entrepreneurial future: Examining the diverse attitudes and motivations of teens across gender and ethnic identity. Journal of Developmental Entrepreneurship 9, no. 3: 177-97.

Winn, J. 2004. Entrepreneurship: Not an easy path to top management for women. Women in Management Review 19, no. 3: 143-53.

www.scp.gov.om

https://www.worldbank.org/en/country/gcc/publication/economic-outlook-april-2018-oman https://bit.ly/2pN9Avx

Yadav, V., \& Unni, J. (2016). Women entrepreneurship: research, review and future directions. Journal of Global Entrepreneurship Research, Vol. 6, No. 12, pp. 1-18. 


\section{TABLES}

Table 1: Company type and age, women entrepreneurs age, education and marital status

\begin{tabular}{|c|c|c|c|}
\hline Item & Classes & Frequency & Percent \\
\hline & Sole Proprietorship & 128 & 90.1 \\
\hline \multicolumn{4}{|c|}{ Company Type } \\
\hline & Partnership & 14 & 9.9 \\
\hline & Less than 2 years & 80 & 56.3 \\
\hline \multirow[t]{3}{*}{ Company Age } & $2-5$ years & 24 & 16.9 \\
\hline & More than 5 years & 38 & 26.8 \\
\hline & Less than 25 years & 22 & 15.5 \\
\hline Entrepreneurs & $25-34$ years & 48 & 33.8 \\
\hline \multirow[t]{3}{*}{ Age } & $35-44$ years & 38 & 26.8 \\
\hline & 45 years and above & 34 & 23.9 \\
\hline & Below high school & 44 & 31.0 \\
\hline Entrepreneurs' & Diploma/senior secondary & 60 & 42.3 \\
\hline \multirow[t]{2}{*}{ Education } & Bachelor degree & 34 & 23.9 \\
\hline & Master/ Ph.D. & 4 & 2.8 \\
\hline Marital status of & Unmarried & 36 & 25.4 \\
\hline \multirow[t]{2}{*}{ Entrepreneurs } & Married & 106 & 74.6 \\
\hline & Total & 142 & 100.0 \\
\hline
\end{tabular}

Table 2: Field of business 


\begin{tabular}{lcc}
\hline Business Field & Frequency & Percent \\
\hline Frankincense/ Perfumes/ Aromas & 50 & 35.2 \\
Apparel/Clothing & 44 & 31.1 \\
Accommodation \& Food Service & 20 & 14.1 \\
Arts, Entertainment \& Recreation & 6 & 4.2 \\
Wholesale \& Retail & 6 & 4.2 \\
Traditional/ Handicrafts & 4 & 2.8 \\
Others & 4 & 2.8 \\
Health \& Social Activities & 3 & 2.1 \\
Agriculture/ Forestry/Fishing & 2 & 1.4 \\
Education \& Related & 2 & 1.4 \\
Construction & 1 & .7 \\
Total & 142 & 100.0 \\
\hline
\end{tabular}

Table 3: Number of employees, income, international trade type, and revenue 


\begin{tabular}{|c|c|c|c|}
\hline Item & Classes & Frequency & Percent \\
\hline & None other than me & 102 & 71.8 \\
\hline \multirow[t]{3}{*}{ Employees No. } & 1-10 employees & 18 & 12.7 \\
\hline & More 10 employees & 22 & 15.5 \\
\hline & Under 500 RO & 101 & 71.1 \\
\hline \multirow[t]{3}{*}{ Income } & $500-1000 \mathrm{RO}$ & 26 & 18.3 \\
\hline & More $1000 \mathrm{RO}$ & 15 & 10.6 \\
\hline & Export & 40 & 28.2 \\
\hline International & Import & 36 & 25.4 \\
\hline \multirow[t]{3}{*}{ Trade Type } & Both & 52 & 36.6 \\
\hline & No & 14 & 9.8 \\
\hline & Increased & 86 & 60.6 \\
\hline \multirow[t]{3}{*}{ Revenue } & Decreased & 14 & 9.9 \\
\hline & Same & 42 & 29.5 \\
\hline & Total & 142 & 100.0 \\
\hline
\end{tabular}


Table 4: Business idea, obstacles, activities, and mentor 


\begin{tabular}{|c|c|c|c|}
\hline Item & Classes & Frequency & Percent \\
\hline & To make more money/ supplement the family income & 75 & 52.8 \\
\hline & To be more independent/ self-owned business & 44 & 31.0 \\
\hline \multicolumn{4}{|c|}{ Main Idea } \\
\hline of & To realize a passion/ role model for the society & 8 & 5.6 \\
\hline \multirow{6}{*}{ Business } & To fill a need, big latent demand for an entirely new product/service & 6 & 4.2 \\
\hline & I inherit the family business & 6 & 4.2 \\
\hline & Identified a very profitable area for business & 3 & 2.1 \\
\hline & Acquiring self-confidence to bear the risk of starting the business & 46 & 32.4 \\
\hline & Availability of time (family issues) & 40 & 28.2 \\
\hline & Availability of financial resources & 32 & 22.5 \\
\hline \multirow[t]{7}{*}{ Obstacles } & Accessing the right social networks & 10 & 7.1 \\
\hline & Acquiring approval/support of the family members & 6 & 4.2 \\
\hline & Acquiring credibility \& trust from others & 5 & 3.5 \\
\hline & Lack of information about the sector & 3 & 2.1 \\
\hline & Participated in a trade fair in your own country & 78 & 54.9 \\
\hline & Attended a training session or a MDP & 32 & 22.5 \\
\hline & $\begin{array}{l}\text { Taken a membership of a business chamber, association or a } \\
\text { cooperative }\end{array}$ & 20 & 14.1 \\
\hline
\end{tabular}

Activities

Organized internal training courses for your employees or

$10 \quad 7.1$

encouraged them to follow external training courses

Been accepted into any sort of government-sponsored business

development/assistance programmer

$2 \quad 1.4$

Your mother

$36 \quad 25.4$

None

30

21.1

Your father

24

16.9 
Already a successful entrepreneur

$12 \quad 8.5$

Your spouse

8

Examples of entrepreneurs in media

6

4.2

Your teacher

2

1.4

Total

142

Table 5: Behaviors in business

\begin{tabular}{|c|c|c|}
\hline Statement & Mean & St.D. \\
\hline I feel confident that I can succeed at whatever I try to do & 4.01 & 1.220 \\
\hline Even if I have set the deadline for delivering a job, my family is more important. & 3.97 & 1.315 \\
\hline Before doing something, I carefully weigh the advantages and disadvantages of different & 3.89 & 1.137 \\
\hline ways of accomplishing it & & \\
\hline I like challenges and new opportunities & 3.85 & 1.138 \\
\hline When something gets in the way of what I'm trying to accomplish, I keep on trying & 3.77 & 1.217 \\
\hline I have a clear idea of what I will do in my working life & 3.75 & 1.426 \\
\hline At work, I seek the advice of people who know more than I do & 3.73 & 1.271 \\
\hline I deal with problems as they arise, rather than wasting time trying to anticipate them & 3.65 & 1.156 \\
\hline I dare to do something new and different, even if people are skeptical & 3.11 & 1.332 \\
\hline I stick with my decisions even when others disagree with me strongly & 2.77 & 1.193 \\
\hline I change my way of thinking if others oppose my point of view & 2.65 & 1.180 \\
\hline I do things that people consider risky & 2.76 & 1.254 \\
\hline
\end{tabular}


Table 6: Improve of support for small businesses

Percent

businesses

Provide basic skills \& training for new \& prospective business owners

Increase efforts to safeguard intellectual property protection for innovative

Support businesses

Establish a special government advisory board or panel for entrepreneurship

and innovation

Change employment laws to increase business flexibility for hiring and

replacing workers

Align tax policies with the encouragement of new business formation and innovative activities

100.0

Table 7: (EFA) Exploratory Factor Analysis of Business Challenges 


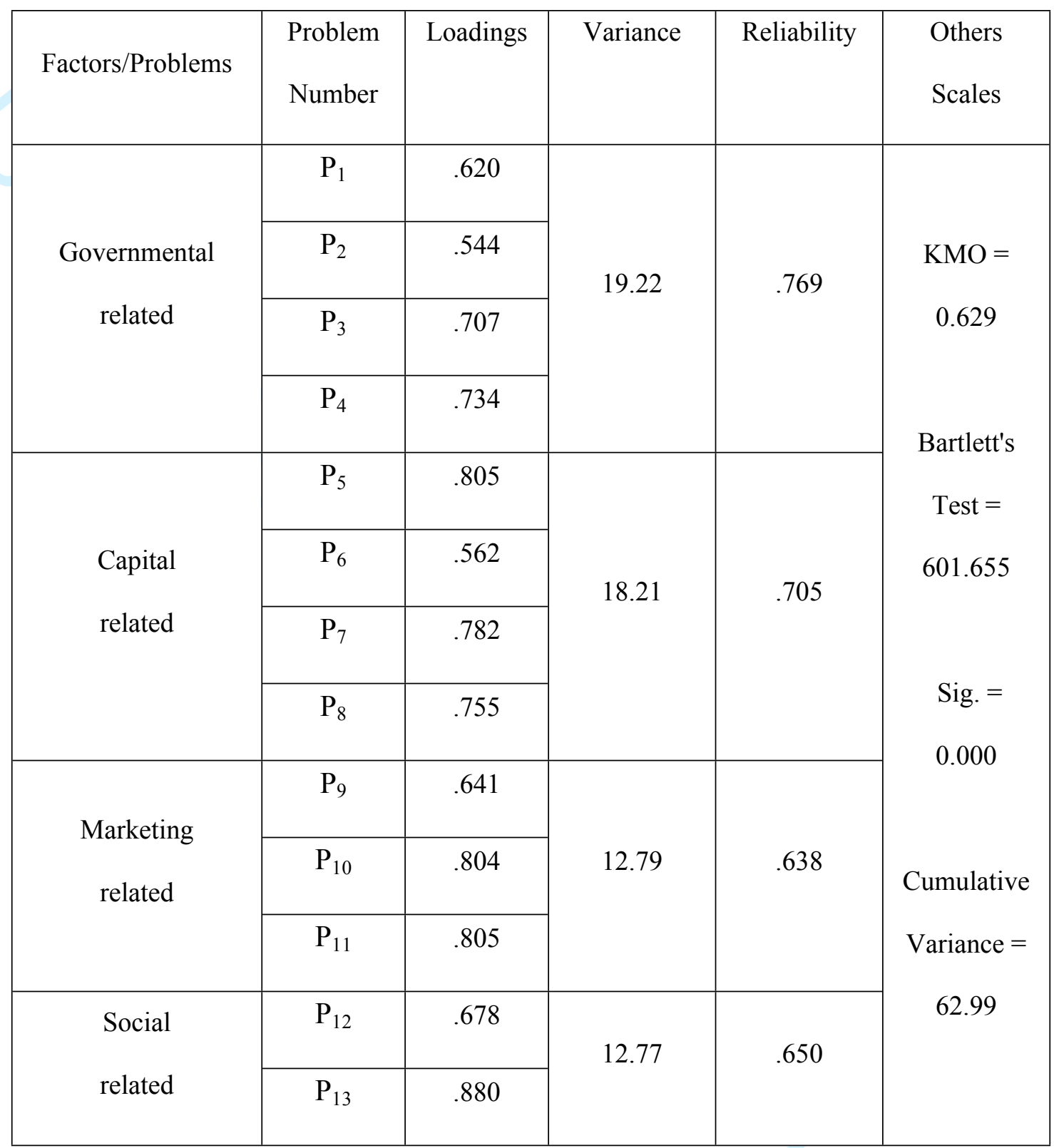




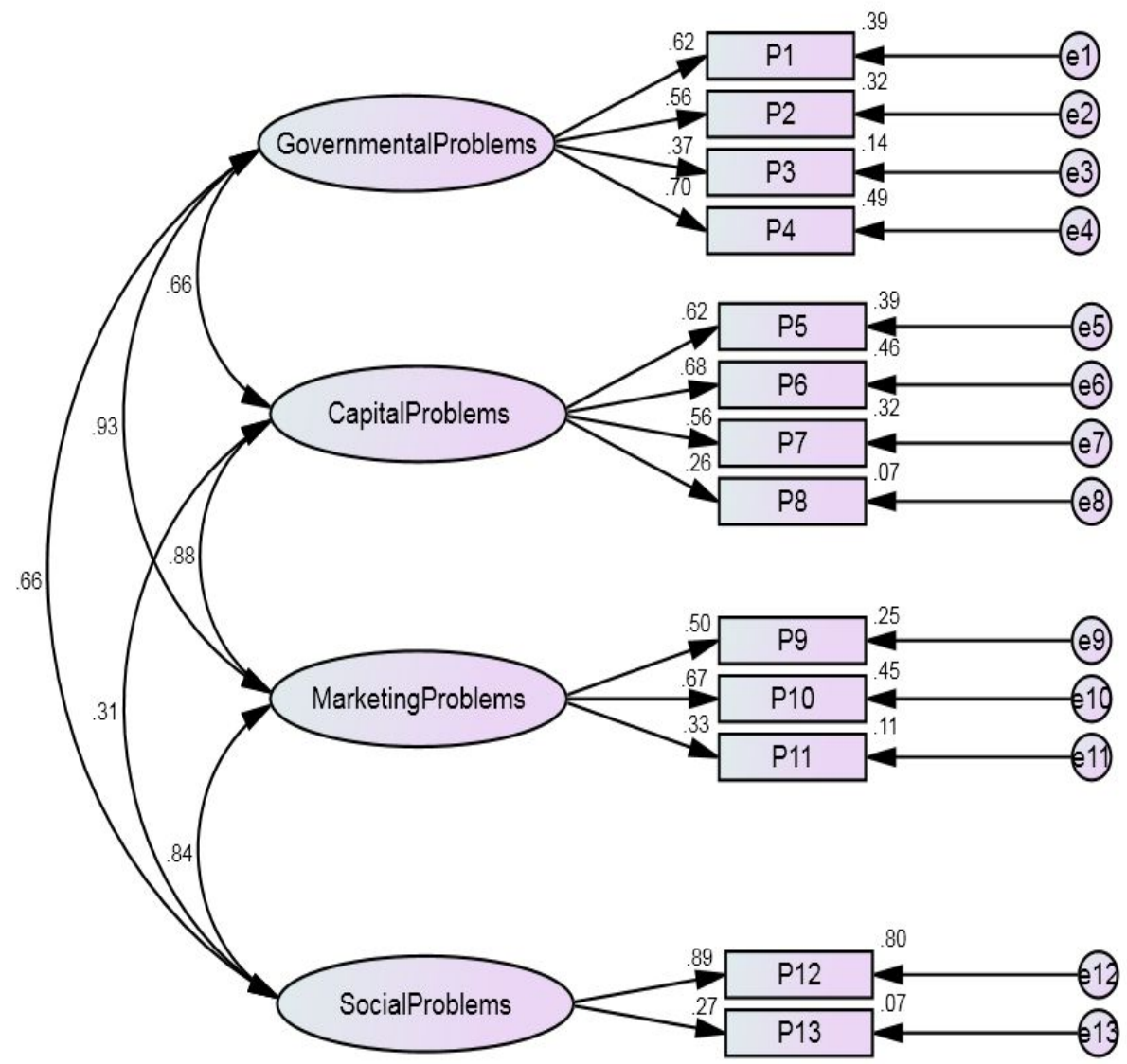

Figure 1: (CFA) Confirmatory Factor Analysis of Study Model

Table 8: Model fit indices 


\begin{tabular}{cccc}
\hline Indices & Symbol & Indices Values & Criteria \\
\hline Chi-Square $\quad(\mathrm{P}=0.000)$ & $\left(\mathrm{X}^{2}=210.957\right)$ & $(\mathrm{DF}=59)$ & $<0.05$ \\
Chi-Square/Degree of Freedom & CMIN/DF & 3.374 & $<5$ \\
Root Mean Square of Approximation & RMSEA & 0.030 & $<0.08$ \\
Root Mean Square Residual & RMR & 0.066 & $<0.08$ \\
Comparative Fit Index & CFI & 0.900 & $>0.9$ \\
Tucker Lewis Index & TLI & 0.903 & $>0.9$ \\
Parsimony Normed Fit Index & PNFI & 0.580 & $>0.5$ \\
Goodness-of-Fit Index & GFI & 0.938 & $>0.9$ \\
Parsimony Goodness-of-Fit Index & PGFI & 0.543 & $>0.5$ \\
\hline
\end{tabular}

Table 9: Importance of the problems in business for women entrepreneurs

\begin{tabular}{|c|c|c|c|c|}
\hline Problems & $\mathrm{S}$ & 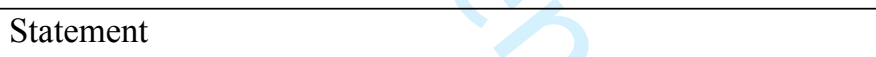 & Mean & St.D. \\
\hline \multirow{4}{*}{ Governmental } & $\mathrm{P}_{1}$ & Reforming laws and regulations that hamper business growth. & 3.39 & 1.352 \\
\hline & $\mathrm{P}_{2}$ & Access to training and technical assistance to learn the business. & 3.38 & 1.276 \\
\hline & $\mathrm{P}_{3}$ & High cost of services (telecom, electricity, travel, etc.). & 3.30 & 1.219 \\
\hline & $\mathrm{P}_{4}$ & Corruption among government officials/Need for payoffs, bribes, etc. & 3.25 & 1.665 \\
\hline \multirow{4}{*}{ Financial } & $\mathrm{P}_{5}$ & Adapting with the emerging trends in technology & 3.93 & 1.207 \\
\hline & $\mathrm{P}_{6}$ & Access of the capital for future business prospects. & 3.79 & 1.214 \\
\hline & $\mathrm{P}_{7}$ & Availability of the capital for current business needs. & 3.58 & 1.621 \\
\hline & $\mathrm{P}_{8}$ & Access to property, land, business premises. & 3.05 & 1.315 \\
\hline Marketing & $\mathrm{P}_{9}$ & Access to specialized suppliers for staying ahead of the competition. & 3.52 & 1.418 \\
\hline
\end{tabular}


Table 10: Mean, Standard Deviation, and Correlations

\begin{tabular}{|c|c|c|c|c|c|c|c|}
\hline No. & Variables & Mean & St.D. & $\mathrm{I}$ & II & III & IV \\
\hline $\mathrm{I}$ & Governmental Problems & 3.330 & .9698 & 1 & & & \\
\hline II & Capital Problems & 3.580 & .8922 & $.465 * *$ & 1 & & \\
\hline III & Marketing Problems & 3.270 & .9567 & $.550 * *$ & $.600 * *$ & 1 & \\
\hline IV & Social Problems & 3.138 & 1.050 & $.372 * *$ & $.302 * *$ & $.405 * *$ & 1 \\
\hline
\end{tabular}

Table 11: T-Test of problems of business, according (Company Type \& Marital Status)

\begin{tabular}{|c|c|c|c|c|}
\hline \multirow{2}{*}{ Business Problems } & \multicolumn{2}{|c|}{ Company Type } & \multicolumn{2}{c|}{ Marital Status } \\
\cline { 2 - 5 } & $\mathrm{t}$ & Sig. & $\mathrm{t}$ & Sig. \\
\hline Governmental Problems & -2.903 & 0.007 & 0.712 & 0.478 \\
\hline Capital Problems & -3.716 & 0.001 & 1.761 & 0.080 \\
\hline Marketing Problems & 2.433 & 0.016 & 1.273 & 0.206 \\
\hline Social Problems & 1.308 & 0.193 & 0.766 & 0.445 \\
\hline
\end{tabular}

Table 12: ANOVA of Emotional Intelligence Dimensions according (Universities \& Age) 


\begin{tabular}{|c|c|c|c|c|c|c|}
\hline \multirow{2}{*}{ Business Problems } & \multicolumn{2}{|c|}{ Age } & \multicolumn{2}{c|}{ Education } & \multicolumn{2}{c|}{ Industry } \\
\cline { 2 - 7 } & F & Sig. & F & Sig. & F & Sig. \\
\hline Governmental & 7.259 & 0.000 & 1.774 & 0.155 & 2.761 & 0.004 \\
Problems & & & & & & \\
\hline Capital Problems & 8.346 & 0.000 & 7.790 & 0.000 & 3.064 & 0.002 \\
\hline Marketing Problems & 5.925 & 0.001 & 0.598 & 0.617 & 2.364 & 0.013 \\
\hline Social Problems & 2.328 & 0.077 & 0.230 & 0.875 & 2.719 & 0.005 \\
\hline
\end{tabular}

